Article

\title{
The Impact of Financial Development on Carbon Emissions: A Global Perspective
}

\author{
Chun Jiang and Xiaoxin Ma * \\ Economics and Management School, Wuhan University, Wuhan 430072, China; jiachun@whu.edu.cn \\ * Correspondence: kymaxx@163.com
}

Received: 16 August 2019; Accepted: 21 September 2019; Published: 25 September 2019

check for updates

\begin{abstract}
Financial development has been deemed to be an important factor influencing carbon emissions; however, the specific effect generated by financial development is still disputed. In this study, we examined the relationship between financial development and carbon emissions based on a system generalized method of moments and the data of 155 countries, and we further analyzed the national differences by dividing the sample countries into two sub-groups: developed countries, and emerging market and developing countries. The empirical results indicated that from a global perspective, financial development could significantly increase carbon emissions, and the analysis of the emerging market and developing countries reached the same conclusion; however, the results indicated that for developed countries, the effect of financial development on carbon emissions is insignificant. A series of robustness checks were conducted and confirmed that our empirical results were reliable. We suggest that policymakers in emerging market and developing countries should carefully balance financial development and environmental protection, as financial development will promote carbon emissions before countries reach a relatively high development level.
\end{abstract}

Keywords: financial development; carbon emission; global perspective; system GMM

\section{Introduction}

The issue of global warming has attracted worldwide attention. It is widely thought that this problem is caused by the excessive emission of greenhouse gases (GHGs), especially carbon dioxide. Many scholars have investigated the relationship between economic growth and carbon emissions, and have tried to determine how to mitigate this circumstance. The most well-known perspective is the environmental Kuznets curve (EKC) hypothesis proposed by Grossman and Krueger [1], which considers an inverted U-shaped relationship between the level of economic development and environmental quality. Many studies have validated the EKC hypothesis [2-4]; however, some scholars have proposed doubts or opposite opinions [5-7].

Many scholars have concentrated on the factors influencing carbon emissions, such as trade openness, urbanization, and population growth. In recent years, scholars have proposed that financial development is another important factor that could significantly affect carbon emissions, and the omission of a financial factor may lead to erroneous empirical results [8,9]. Therefore, scholars have conducted a series of studies on the influence of financial development on carbon emissions with different methodologies, indexes, and samples. The relevant research has not yet reached a consistent conclusion.

In this study, we analyzed the relationship between financial development and carbon emissions from a global perspective, on which scholars have rarely focused. We further divided the sample countries into two groups: developed countries, and emerging market and developing countries, which allowed us to detect the national differences in a unified framework. 
The rest of this paper is arranged as follows: Section 2 provides a literature review, Section 3 describes the empirical strategy and sample data, Section 4 provides the empirical results and discussion, Section 5 outlines the robustness checks, Section 6 discusses the empirical results, limitations and further research direction, and Section 7 provides the conclusion and policy implications.

\section{Literature Review}

\subsection{Theoretical Perspective}

From the theoretical perspective of the influence of financial development on carbon emissions, scholars have proposed contradictory viewpoints. Some scholars $[8,10,11]$ report that financial development could help reduce carbon emissions because of the following aspects: (1) in order to reduce production costs and enhance the market competitiveness of products, enterprises need to periodically update production technology and equipment which rely on adequate financial support. A developed financial system could facilitate enterprises to complete these works by effectively mitigating their financing constraints, which further indirectly decrease energy costs and reduce carbon emissions; (2) for the purpose of coping with environment degradation, governments generally tend to launch various environmentally friendly projects, promote overall industrial transformation, and the use of clean energy. Based on the corresponding policy arrangement, the financial institutions could provide necessary funds for the operation of these projects or programs, which could help to improve the energy infrastructure and finally reduce carbon emissions; (3) the enterprises listed on the stock market are generally outstanding enterprises which have significant influence on national economy. Due to the requirement of the stock exchange, they need to undertake regular information disclosure and are subject to strict supervision of the financial authorities and the public. This enforces them to establish a good image, such as assuming the social responsibility of environmental protection by utilizing environmentally friendly technologies, which could reduce carbon emissions. These can be called the "negative effects" of financial development on carbon emissions.

Other scholars [12-14] consider that financial development increases carbon emissions due to the following reasons: (1) a well functioned financial system could effectively relieve the problem of information asymmetry, expand financing channels, to enable the enterprises to obtain lending capitals with much lower costs which facilitate their expansion of the production scale (such as building a new production line, renting more equipment, and employing more workers), and therefore significantly increase carbon emissions; (2) likewise, the development of the financial sector could provide more and better service of consumption credit, which facilitates their intertemporal consumption and encourages them to purchase more commodities such as properties, automobiles, and other electric appliances. These would dramatically promote the expansion of social consumption and further increase carbon emissions; (3) the stock market generally acts as an important barometer of economic conditions, good performance of the stock market often implies the rapid growth and prosperity of the economy, which in turn greatly enhances the confidence of enterprises and consumers and stimulates the activities of production and consumption, therefore leading to the increase of energy consumption and carbon emissions. These can be called the "positive effects" of financial development on carbon emissions.

\subsection{Empirical Research}

To provide empirical evidence for the nexus of financial development and carbon emissions, scholars have conducted abundant research with different models and samples; however, these studies still do not yet provide a consensus. Overall, there are three main viewpoints in the empirical research: financial development reduces carbon emissions, increases carbon emissions, and other perspectives.

\subsubsection{Financial Development Reduces Carbon Emissions}

Tamazian and Rao [15] study the relationship between financial development and environmental degradation with a system generalized method of moments (GMM) estimation and the panel data 
of 24 transition economies from 1993-2004. They conclude that in transitional economies, financial development plays a positive role in environmental disclosure and can help to reduce carbon emissions.

Saidi and Mbarek [16] investigate the influence of financial development on carbon emissions based on a system GMM model and the time series data of 19 emerging economies from 1990-2013. The empirical results indicate that financial development has had a long-term negative impact on carbon emissions, which indicates that environmental degradation could be minimized by financial development.

Based on the time series data from South Africa for 1965-2008, and using the autoregressive distributed lag (ARDL) bounds testing approach for the cointegration and error correction method, Shahbaz et al. [9] find that financial development can reduce carbon emissions, which implies that financial reforms can be introduced to help maintain or improve the environment.

Omri et al. [17] study the relationship between financial development and carbon emissions using the simultaneous-equation panel data model and the data of 12 Middle East and North Africa (MENA) countries for the period of 1990 to 2011. The results show that higher levels of financial system development could increase the input of energy conservation R\&D, which can promote technological innovations and eventually lower carbon emissions.

Using dynamic ordinary least squares (DOLS) and fully modified ordinary least squares (FMOLS) methods, Dogan and Seker [18] research the long-run dynamic relationship of financial development and carbon emissions based on the panel data of 23 top renewable energy countries from 1985-2011; they find that the analyzed variables are cointegrated and financial development could reduce carbon emissions.

Zaidi et al. [19] examine the dynamic relationship of financial development and carbon emissions in the EKC framework with continuously updated bias-corrected (CUP-BC) and continuously updated fully modified (CUP-FM) methods and the panel data of 17 Asia Pacific Economic Cooperation (APEC) countries from 1990-2016. The empirical results indicate that the financial development could reduce carbon emissions both in the long-run and short-run. Similarly, Zafar et al. [20] find this conclusion is also valid for Organization for Economic Co-operation and Development (OECD) countries.

\subsubsection{Financial Development Increases Carbon Emission}

Al-Mulali et al. [21] investigate the relationship between financial development and carbon emission in 23 selected European countries with the panel-pooled FMOLS model and conclude that financial development could increase carbon emissions in the long-run.

Zhang [13] consider financial development as one of the main factors that increase carbon emissions in China using a series of empirical methods and a couple of proxy variables for financial development. The research also discovers that the financial intermediation scale had the most outstanding influence on carbon emissions compared with other indictors of financial development.

Shahbaz et al. [22] examine the asymmetric impact of financial development on carbon emission in Pakistan with quarterly data from Q1 1985 to Q4 2014, and a calculated comprehensive index of financial development based on bank and stock-market indicators. The results indicate that financial development in the banking sector could increase carbon emissions via positive shocks, and this appears to be a unidirectional causality.

Bekhet et al. [23] examine the relationship between financial development and carbon emissions in Gulf Cooperation Council (GCC) countries with the ARDL model, and the empirical results indicate that the unidirectional causality of financial development to carbon emissions exists in the United Arab Emirates (UAE), Oman, and Kuwait.

$\mathrm{Lu}$ [24] studies the causality relationship between financial development and carbon emissions based on a panel causality test and the panel data of 12 Asian countries from 1993-2013. The empirical result shows that financial development causes carbon emissions.

Cetin et al. [25] examine the influence of financial development on carbon emissions in Turkey based on an ARDL bounds testing approach and vector error correction model (VECM) Granger 
causality test and the annual time series data for the period of 1960-2013. They discover a positive relationship between financial development and carbon emissions in the long-run, and the causality test reveals the unidirectional causality running from financial development to carbon emissions. Similarly, Ali et al. [26] study the dynamic links between financial development and carbon emissions in Nigeria with the ARDL bound test approach and the data period of 1971-2010, and conclude that financial development has a positive and significant impact on carbon emissions in both the long-run and short-run.

\subsubsection{Other Perspectives}

Dogan and Turkekul [14] analyze the relationship between financial development and carbon emissions in the USA from 1960 to 2010 with the ARDL approach and error correction-based Granger causality test, and conclude that although the financial development could affect the output, it has no effect on carbon emissions in the long-term. Similarly, based on the panel vector autoregressive (PVAR) model and the data of 24 countries in the MENA region from 1980 to 2015, Charfeddine and Kahia [27] find that financial development only slightly influences carbon emissions.

Paramati et al. [28] investigate the relationship between stock markets and carbon emissions in 23 developed and 20 emerging market countries from 1992 to 2011 with the Durbin-Hausman test and the common correlated effects (CCE) approach, and find that the influence of the stock market on carbon emissions differs between developed countries and emerging market countries. More specifically, the stock market indicators significantly negatively affect carbon emissions in developed countries but positively affects emerging market countries.

\subsection{Comment and Discussion}

From the above literature review, we can discover that the influence of financial development on carbon emissions is still under debate in both the theoretical and empirical research, which reflect the complexity of their relationship which cannot be readily detected or described.

Specifically, the theoretical research reveals that the financial development has both positive and negative effects on carbon emissions, the aggregate effect might be determined by the relative size of these positive and negative effects. The empirical research reflects that the influence of financial development on carbon emissions varies across countries and regions. Actually, it also demonstrates the viewpoint of the theoretical research to some extent, as it is reasonable to consider both the positive and negative effects are divergent in different countries and regions. Although the influence of financial development on carbon emissions remains in dispute, the relevant research on this topic have provided important theoretical values for environmental policy making.

However, two limitations exist in the literature on this topic: firstly, most of the researchers selected regional or individual country samples as the research objects, but few focused on this issue from a global perspective; secondly, the application of different methods, samples, and data, has created challenges for comparing research completed by different scholars.

Considering the above limitations, we collected a comprehensive country sample that contained the data of 155 countries to analyze the influence of financial development on carbon emissions from the global perspective, in order to provide more empirical evidence on this topic.

\section{Empirical Strategy and Data}

\subsection{Empirical Model and Methodology}

In this paper, we focused on three research objectives: first of all, we analyzed the influence of financial development on carbon emissions from the global perspective based on panel data of 155 countries, which could enable us to detect their relationship on a macro angle; in addition, we researched this issue by dividing the sample countries into two sub-groups-developed countries, and emerging market and developing countries, to detect national differences under a unified analytical framework. 
The discrepancy of the empirical results reflects the heterogeneous effect of financial development on carbon emissions in different countries and regions. However, due to the inconsistent samples, proxy variables and methodologies adopted by scholars, it was quite difficult to compare their empirical results in a unified framework. Therefore, after the full sample analysis, we further divided our sample into different sub-groups to examine the national effect of financial development on carbon emissions across different types of countries, in the same empirical framework. According to general practice in the empirical works [29-31], we divided our sample countries into two sub-groups-developed countries, and emerging market and developing countries, as it is widely believed by the scholars that a significant discrepancy in the aspects of economic structure, technical level, and resource endowment exists between these two groups, which may result remarkable implications on macro factors (please refer to Appendix A for more information about the country classification); lastly, we investigated the influence of different aspects of financial development on carbon emissions by adopting a series proxy variables of financial development. Much research deems financial development as a unique concept and takes one or two indexes to be its proxy variables. Actually, scholars commonly believe that financial development has rich connotation that can be divided into different aspects, therefore, besides the use of a comprehensive index, we further adopted five concrete indexes of financial development to analyze the effect of different aspects of financial development on carbon emissions, apart from its aggregate effect, to provide more specific evidence on this topic.

Considering the above research objectives and following the general practice on this topic $[15,21,28]$, we established the dynamic panel model below:

$$
C E_{i t}=\alpha+\beta_{0} C E_{i t-1}+\beta_{1} F D_{i t}+\gamma \text { Control }_{i t}+\mu_{i}+\varepsilon_{i t}
$$

where $C E_{i t}$ represents carbon emission; $F D_{i t}$ signifies financial development; $C$ ontrol ${ }_{i t}$ denotes a series of control variables; $\beta_{0}, \beta_{1}$, and $\gamma$ are the corresponding coefficients; $\mu_{i}$ represents the unobserved country specific effect; $\varepsilon_{i t}$ is the residual term; and $i$ and $t$ indicate the country and time, respectively.

We introduced the lag-term of carbon emissions into the regression equation to reflect the dynamic process of carbon emissions, which was consistent with reality. Adding a lag-term can eliminate the influence of uncontrollable factors, increasing the credibility of the regression results.

As a result of the existence of a lag-term, the model could not be estimated by ordinary least squares (OLS) or traditional panel model estimation methods (such as fixed-effect or random-effect), as they would have caused an endogenous problem and therefore could not provide effective estimators. To solve this problem, we adopted the generalized method of moments (GMM) [32-34] to estimate the above model. GMM can be divided into difference GMM and system GMM; each of them can further be divided into one-step and two-step estimation methods according to the selection of different weight matrixes.

Compared with the difference GMM, the system GMM can help mitigate the problems of weak tools and limited sample errors and can improve the efficiency of estimation. The two-step estimation performed better in handling the autocorrelation and heteroscedasticity problems than one-step estimation. Therefore, we adopted a two-step system GMM method to estimate our model. We adopted Stata (StataCorp, College Station, Texas, USA) and the command "xtabond2" to complete the estimations. Please refer to Roodman [35] for more details about this command. We conducted the test of serial correlation and the effectiveness of instrument variables to examine the consistency of the estimators, based on relevant statistics. In addition, the Hansen test was used to judge the effectiveness of the instrument variables rather than the Sargan test, as Roodman [35] shows that the Sargan test is not robust to heteroscedasticity or autocorrelation.

\subsection{Data}

So far, no indictors are widely accepted as proxy variables of financial development due to their rich and complex connotation. Scholars adopt many different indicators according to their research 
objectives and the data availability [36-40]. In our research, we used the comprehensive index of financial development proposed by Svirydzenka [41] in the main regression, which allowed us to investigate the "aggregate" effect of financial development on carbon emissions. Please refer to Appendix B for more information of this index.

To analyze the influence of different aspects of financial development on carbon emissions and to guarantee the reliability and accuracy of the empirical results, we also adopted another five variables as the proxies of financial development besides the comprehensive index proposed by Svirydzenka [41].

Following the common research on carbon emissions [27,42,43], we used carbon dioxide emissions (metric tons per capita) as its proxy, and selected four control variables: trade openness, urbanization, population growth, and industrial structure. The details of the variables used in our model are presented in Table 1.

Table 1. Variable descriptions.

\begin{tabular}{|c|c|c|}
\hline Variables & Symbol & Measurable Indicator \\
\hline Carbon emission & $\mathrm{CE}$ & carbon dioxide emissions (metric tons per capita) \\
\hline Financial development 1 & FD1 & A comprehensive index proposed by Svirydzenka [41] \\
\hline Financial development 2 & FD2 & Domestic credit to the private sector ( $\%$ of GDP) \\
\hline Financial development 3 & FD3 & Domestic credit provided by the financial sector (\% of GDP) \\
\hline Financial development 4 & FD4 & Domestic credit to the private sector by banks ( $\%$ of GDP) \\
\hline Financial development 5 & FD5 & Total value of traded stocks ( $\%$ of GDP) \\
\hline Financial development 6 & FD6 & Market capitalization of listed domestic companies (\% of GDP) \\
\hline Trade openness & TRADE & Total import and export (\% of GDP) \\
\hline Urbanization & URBAN & Urban population (\% of total population) \\
\hline Population growth & POP & Population growth $(\%)$ \\
\hline Industrial structure & IND & Industrial value added (\% of GDP) \\
\hline
\end{tabular}

Note: GDP denotes gross domestic product.

According to the data availability, our sample contained 155 countries, including 35 developed countries and 120 emerging market and developing countries. The main regression data cover the period from 1990 to 2014, and in the robustness checks, the period was extended to 1960-2014. All the variables were extracted from the World Development Indicators database of the World Bank, except for the financial development (FD)1 variable, which was sourced from the International Monetary Fund (IMF) database. All the variables were transformed into the natural logarithms to reduce nonnormality and heteroscedasticity [44], except for FD1 and population growth (POP) as they were already dimensionless or ratio indexes. Table 2 displays the descriptive statistics of the variables for the main regression. We adopted several regressions in the section of empirical analysis, and to save space, the descriptive statistics of the other regressions are not presented but are available from the authors upon request.

Table 2. Descriptive statistics of main regression.

\begin{tabular}{cccccc}
\hline Variable & Obs. & Mean & SD & Min & Max \\
\hline CE & 3875 & 4.401446 & 5.217805 & 0.0107325 & 35.67826 \\
FD1 & 3875 & 0.2996452 & 0.2147667 & 0.0001266 & 1 \\
TRADE & 3875 & 84.90056 & 51.85297 & 0.1674176 & 442.62 \\
URBAN & 3875 & 54.68968 & 22.93943 & 5.416 & 100 \\
POP & 3875 & 1.469806 & 1.403123 & -9.080639 & 14.23679 \\
IND & 3875 & 27.02753 & 11.72264 & 2.525526 & 87.79689 \\
\hline
\end{tabular}

Note: Obs. denotes number of observations. SD denotes standard deviation.

Table 3 presents the correlation matrix of all the variables in the main regression. Generally, when all the correlation coefficients of each of the variables are less than 0.85 , the model is considered to not have a multicollinearity problem $[45,46]$. Table 3 shows that all the correlation coefficients were less than 0.85 ; therefore, we thought that our model was not affected by the multicollinearity problem. 
We also calculated the correlation matrixes for other regressions besides the main regression; all of the correlation coefficients were less than 0.85 .

Table 3. Correlation matrix of the variables.

\begin{tabular}{ccccccc}
\hline Variable & CE & FD & TRADE & URBAN & POP & IND \\
\hline CE & 1.0000 & & & & & \\
FD1 & 0.5765 & 1.0000 & & & & \\
TRADE & 0.2780 & 0.2535 & 1.0000 & & & \\
URBAN & 0.5913 & 0.6162 & 0.2600 & 1.0000 & & \\
POP & -0.0875 & -0.2779 & -0.0557 & -0.2083 & 1.0000 & \\
IND & 0.2889 & 0.0028 & 0.0239 & 0.2666 & 0.0687 & 1.0000 \\
\hline
\end{tabular}

\section{Results and Comments}

\subsection{Unit Root Test and Co-Integration Test}

In the panel models, non-stationary sequences data cause the problem of spurious regression, which further leads to errors in estimating the results. To avoid this circumstance, we adopted five commonly-used unit root tests [47-51] to examine the stationarity of the data. Note, to save space, we only report the results of the unit-root test and co-integration test for the main regression (full sample); all the other regressions also passed these two tests, and the results are available from the authors upon request. Table 4 displays the results of the unit root test. All the variables were stationary sequences. However, as some of the variables were not significant in certain unit root tests, we examined the stationarity of the first-order difference of the variables, and the results indicated that all the unit root tests were significant at the $1 \%$ level, which implied that all the variables were at least integrated at an order of one. We further investigated the co-integration relationship among the panel data series using three co-integration tests [52-54]. The results in Table 5 show that the null hypotheses of "no co-integration" were rejected by all three tests, which implied that the co-integration relationship did exist; therefore, we continued our research by establishing the panel data model.

Table 4. Panel unit root test.

\begin{tabular}{|c|c|c|c|c|c|c|}
\hline Variable & LLC & IPS & HT & Breitung & Fisher & Result \\
\hline CE & $\begin{array}{c}-9.7494^{* * *} \\
(0.0000)\end{array}$ & $\begin{array}{c}-2.6540 * * * \\
(0.0040)\end{array}$ & $\begin{array}{c}0.7965^{* * *} \\
(0.0000)\end{array}$ & $\begin{array}{c}-4.4546^{* * *} \\
(0.0000)\end{array}$ & $\begin{array}{c}-14.4344^{* * *} \\
(0.0000)\end{array}$ & Stationary \\
\hline FD1 & $\begin{array}{c}-2.0384 * * \\
(0.0208)\end{array}$ & $\begin{array}{c}-7.1101^{* * * *} \\
(0.0000)\end{array}$ & $\begin{array}{c}0.6864^{* * *} \\
(0.0054)\end{array}$ & $\begin{array}{l}-0.9862 \\
(0.1620)\end{array}$ & $\begin{array}{c}-20.1141^{* * *} \\
(0.0000)\end{array}$ & Stationary \\
\hline TRADE & $\begin{array}{c}-2.0984 \text { ** } \\
(0.0179)\end{array}$ & $\begin{array}{c}-8.7928^{* * * *} \\
(0.0000)\end{array}$ & $\begin{array}{c}0.9668^{* * *} \\
(0.0000)\end{array}$ & $\begin{array}{l}-0.3006 \\
(0.3819)\end{array}$ & $\begin{array}{c}-18.4495 * * * \\
(0.0000)\end{array}$ & Stationary \\
\hline URBAN & $\begin{array}{c}-7.5215^{* * *} \\
(0.0000)\end{array}$ & $\begin{array}{c}-4.2556^{* * *} \\
(0.0000)\end{array}$ & $\begin{array}{l}0.9911^{* *} \\
(0.0277)\end{array}$ & $\begin{array}{c}-2.5344 * * * \\
(0.0056)\end{array}$ & $\begin{array}{c}-12.2500^{* * *} \\
(0.0000)\end{array}$ & Stationary \\
\hline POP & $\begin{array}{c}-3.5694^{* * *} \\
(0.0002)\end{array}$ & $\begin{array}{c}-13.4064^{* * *} \\
(0.0000)\end{array}$ & $\begin{array}{c}0.6788^{* * *} \\
(0.0010)\end{array}$ & $\begin{array}{c}-5.8143^{* * *} \\
(0.0000)\end{array}$ & $\begin{array}{c}-21.4217^{* * *} \\
(0.0000)\end{array}$ & Stationary \\
\hline IND & $\begin{array}{l}-1.1602 \\
(0.1230)\end{array}$ & $\begin{array}{c}-5.8703^{* * *} \\
(0.0000)\end{array}$ & $\begin{array}{c}0.9803^{* * *} \\
(0.0000)\end{array}$ & $\begin{array}{c}-4.9941^{* * *} \\
(0.0000)\end{array}$ & $\begin{array}{c}-18.2061^{* * *} \\
(0.0000)\end{array}$ & Stationary \\
\hline D.CE & $\begin{array}{c}-28.9265^{* * *} \\
(0.0000)\end{array}$ & $\begin{array}{c}-46.1653^{* * *} \\
(0.0000)\end{array}$ & $\begin{array}{c}-0.0992^{* * *} \\
(0.0000)\end{array}$ & $\begin{array}{c}-3.3300 * * * \\
(0.0004)\end{array}$ & $\begin{array}{c}-25.42322^{* * *} \\
(0.0000)\end{array}$ & Stationary \\
\hline D.FD1 & $\begin{array}{c}-14.3504^{* * *} \\
(0.0000)\end{array}$ & $\begin{array}{c}-46.3067^{* * *} \\
(0.0000)\end{array}$ & $\begin{array}{c}-0.0513^{* * *} \\
(0.0000)\end{array}$ & $\begin{array}{c}-20.3993^{* * *} \\
(0.0000)\end{array}$ & $\begin{array}{c}-27.1963^{* * *} \\
(0.0000)\end{array}$ & Stationary \\
\hline
\end{tabular}


Table 4. Cont.

\begin{tabular}{|c|c|c|c|c|c|c|}
\hline Variable & LLC & IPS & HT & Breitung & Fisher & Result \\
\hline D.TRADE & $\begin{array}{c}-35.4105^{* * *} \\
(0.0000)\end{array}$ & $\begin{array}{c}-40.3827^{* * *} \\
(0.0000)\end{array}$ & $\begin{array}{c}-0.0499^{* * *} \\
(0.0000)\end{array}$ & $\begin{array}{c}-5.9384^{* * *} \\
(0.0000)\end{array}$ & $\begin{array}{c}-28.3424^{* * *} \\
(0.0000)\end{array}$ & Stationary \\
\hline D.URBAN & $\begin{array}{c}-11.2854^{* * *} \\
(0.0000)\end{array}$ & $\begin{array}{c}-7.3126^{* * *} \\
(0.0000)\end{array}$ & $\begin{array}{c}0.8334^{* * *} \\
(0.0000)\end{array}$ & $\begin{array}{c}-7.2693^{* * *} \\
(0.0000)\end{array}$ & $\begin{array}{c}-17.5905^{* * *} \\
(0.0000)\end{array}$ & Stationary \\
\hline D.POP & $\begin{array}{c}-25.2584^{* * *} \\
(0.0000)\end{array}$ & $\begin{array}{c}-28.1894^{* * *} \\
(0.0000)\end{array}$ & $\begin{array}{c}-0.1676^{* * *} \\
(0.0000)\end{array}$ & $\begin{array}{c}-5.4290 * * * \\
(0.0000)\end{array}$ & $\begin{array}{c}-29.6550 * * * \\
(0.0000)\end{array}$ & Stationary \\
\hline D.IND & $\begin{array}{c}-35.4769 * * * \\
(0.0000)\end{array}$ & $\begin{array}{c}-40.1566^{* * *} \\
(0.0000)\end{array}$ & $\begin{array}{c}-0.0186^{* * *} \\
(0.0000)\end{array}$ & $\begin{array}{c}-8.0727^{* * *} \\
(0.0000)\end{array}$ & $\begin{array}{c}-26.1916^{* * *} \\
(0.0000)\end{array}$ & Stationary \\
\hline
\end{tabular}

Notes: CE denotes carbon emission. FD1 denotes financial development 1. TRADE denotes trade openness. URBAN denotes urbanization. POP denotes population growth. IND denotes industrial structure. D. denotes the first-order difference of each variable. LLC denotes Levin-Lin-Chu test. IPS denotes Im-Pesaran-Shin test. HT denotes Harris-Tzavalis test. The values in parentheses are the $p$-values. ${ }^{* * *}, * *$, and ${ }^{*}$ indicate significance at $1 \%$, $5 \%$, and $10 \%$ levels, respectively.

Table 5. Co-integration test.

\begin{tabular}{cc}
\hline Method & Statistics \\
\hline \multirow{2}{*}{ Kao } & $-3.6924^{* * *}$ \\
& $(0.0001)$ \\
\hline \multirow{2}{*}{ Pedroni } & $15.0573^{* * *}$ \\
& $(0.0000)$ \\
\hline \multirow{2}{*}{ Wester Lund } & $-3.1521^{* * *}$ \\
& $(0.0008)$ \\
\hline
\end{tabular}

Notes: Values in parentheses are the $p$-values. ${ }^{* * *}, * *$, and ${ }^{*}$ indicate significance at $1 \%, 5 \%$, and $10 \%$ levels, respectively.

\subsection{Result of Full Sample Regression}

Table 6 presents the full sample of the empirical results of the effect of financial development on carbon emissions with stepwise regressions. For all the regressions, the first-order serial correlation tests were significant at the 1\% level, and the second-order serial correlation tests and Hansen tests were not significant. These misspecification tests proved the appropriateness of the GMM specification. The results of the regression showed that financial development had a positive effect on carbon emissions, as the coefficients were positive and significant at the $1 \%$ level. This implied that financial development could increase carbon emissions from a global perspective. The stepwise regressions indicated that our main conclusion was not affected by the change in the control variables.

Table 6. Results of the full sample regression.

\begin{tabular}{cccccc}
\hline Variable & \multicolumn{5}{c}{ Full Sample } \\
\hline \multirow{2}{*}{ L.CE } & $0.8590315^{* * *}$ & $0.8564305^{* * *}$ & $0.7609177^{* * *}$ & $0.7791862^{* * *}$ & $0.7701393^{* * *}$ \\
& $(0.0273400)$ & $(0.0277124)$ & $(0.0499821)$ & $(0.0512527)$ & $(0.0535405)$ \\
\hline \multirow{2}{*}{ FD1 } & $0.6984505^{* * *}$ & $0.6733399^{* * *}$ & $0.6195633^{* * *}$ & $0.5359521^{* * *}$ & $0.6058228^{* * *}$ \\
& $(0.1477555)$ & $(0.1434213)$ & $(0.1505502)$ & $(0.1379598)$ & $(0.1408755)$ \\
\hline \multirow{2}{*}{ TRADE } & - & $0.0748495^{* * *}$ & $0.0866933^{* * *}$ & $0.0793764^{* * *}$ & $0.0777544^{* *}$ \\
& & $(0.0241799)$ & $(0.0320083)$ & $(0.0280387)$ & $(0.0316622)$ \\
\hline \multirow{2}{*}{ URBAN } & - & - & $0.4064496^{* * *}$ & $0.3622845^{* * *}$ & $0.3300433^{* * *}$ \\
& & & $(0.0934621)$ & $(0.0877871)$ & $(0.0845282)$ \\
\hline
\end{tabular}


Table 6. Cont.

\begin{tabular}{cccccc}
\hline Variable & \multicolumn{5}{c}{ Full Sample } \\
\hline POP & - & - & - & $\begin{array}{c}-0.0343910^{* *} \\
(0.0172426)\end{array}$ & $\begin{array}{c}-0.0367518^{* *} \\
(0.0167301)\end{array}$ \\
\hline IND & - & - & - & $\begin{array}{c}0.1540209^{* * *} \\
(0.0475216)\end{array}$ \\
\hline Constant & $-0.1224928^{* * *}$ & $-0.4343379 * * *$ & $-1.9999469^{* * *}$ & $-1.7304080^{* * *}$ & $-2.1036362^{* * *}$ \\
& $(0.0367231)$ & $(0.1237564)$ & $(0.4426030)$ & $(0.4008894)$ & $(0.5139327)$ \\
\hline Number of & 155 & 155 & 155 & 155 & 155 \\
countries & $-6.03 * * *$ & $-6.04^{* * *}$ & $-5.76^{* * *}$ & $-5.79 * * *$ & $-5.80 * * *$ \\
AR (1) & $(0.000)$ & $(0.000)$ & $(0.000)$ & $(0.000)$ & $(0.000)$ \\
\hline AR (2) & -0.21 & -0.33 & -0.40 & -0.27 & -0.01 \\
& $(0.831)$ & $(0.743)$ & $(0.691)$ & $(0.786)$ & $(0.992)$ \\
\hline \multirow{2}{*}{ Hansen test } & 149.62 & 150.74 & 147.61 & 146.89 & 145.29 \\
& $(0.140)$ & $(0.126)$ & $(0.167)$ & $(0.178)$ & $(0.203)$ \\
\hline
\end{tabular}

Note: L. denotes the first-order lag term of variables. AR (1) denotes the first-order autocorrelation estimator. AR (2) denotes the second-order autocorrelation estimator. Values in parentheses are standard errors. For AR (1), AR (2), and the Hansen test, the values in parentheses are the $p$-values. ${ }^{* * *},{ }^{* *}$, and ${ }^{*}$ indicate significance at $1 \%, 5 \%$, and $10 \%$ levels, respectively. These notes are the same for the following tables.

According to the theoretical analysis, the influence of financial development on carbon emissions is uncertain. Some scholars $[8,10,11]$ consider that financial development could fund the innovative activities of enterprises and environmentally friendly projects, which improve productivity and decrease the use of energy, thereby reducing carbon emissions. This can be called the "negative effect" of financial development on carbon emissions. However, other scholars [12-14] report that the development of the financial sector could stimulate the demand for energy consumption and the expansion of production scale, which increase carbon emissions. This can be called the "positive effect" of financial development on carbon emissions. Overall, the total impact is determined by the relative size of the negative and positive effects $[18,55]$. The empirical results indicated that the positive effect exceeds the negative effect in our sample and occupied the dominant position. Therefore, this result showed that on a worldwide level, the effect of financial development was more a promotion than reduction of carbon emissions. This conclusion is consistent with the work of Al-Mulali et al. [21], Bekhet et al. [23], and Lu [24].

\subsection{Results of Sub-Sample Regressions}

The above empirical analysis proved that from a global perspective, financial development has a positive effect on carbon emissions. However, this conclusion may not be valid for countries in different stages of development, as these countries have an obvious discrepancy in economic structure, technical level, and resource endowment. Therefore, we further analyzed the relationship between financial development and carbon emissions by dividing the sample countries into the following two groups: developed countries, and emerging market and developing countries. Table 7 presents the regression results. 
Table 7. Results of the sub-sample regressions.

\begin{tabular}{ccc}
\hline Variable & Developed Countries & Emerging Market and Developing Countries \\
\hline \multirow{2}{*}{ L.CE } & $0.9560886^{* * *}$ & $0.7292117^{* * *}$ \\
& $(0.0864221)$ & $(0.0591621)$ \\
\hline \multirow{2}{*}{ FD1 } & 0.0251260 & $1.2738184^{* * *}$ \\
& $(0.0533522)$ & $(0.2792448)$ \\
\hline \multirow{2}{*}{ TRADE } & -0.0036297 & $0.1034371^{* *}$ \\
& $(0.0110794)$ & $(0.0503334)$ \\
\hline \multirow{2}{*}{ URBAN } & 0.0181402 & $0.3817556^{* * *}$ \\
& $(0.0320493)$ & $(0.0855947)$ \\
\hline \multirow{2}{*}{ POP } & 0.0060512 & $-0.0398173^{* *}$ \\
& $(0.0091576)$ & $(0.0182942)$ \\
\hline \multirow{2}{*}{ IND } & 0.0334594 & $0.12754433^{* * *}$ \\
& $(0.0432423)$ & $(0.0491280)$ \\
\hline \multirow{2}{*}{ Constant } & -0.1030257 & $-2.4493158^{* * *}$ \\
& $(0.1206784)$ & $(0.5447357)$ \\
\hline Number of countries & 35 & 120 \\
\hline \multirow{2}{*}{ AR (1) } & $-3.12 * * *$ & $-5.26^{* * *}$ \\
& $(0.002)$ & $(0.000)$ \\
\hline \multirow{2}{*}{ AR (2) } & -0.29 & -0.02 \\
& $(0.773)$ & $(0.986)$ \\
\hline \multirow{2}{*}{ Hansen test } & 30.51 & 113.98 \\
& $(0.135)$ & $(0.430)$ \\
\hline
\end{tabular}

Note: ${ }^{* * *}, * *$, and ${ }^{*}$ indicate significance at $1 \%, 5 \%$, and $10 \%$ levels, respectively.

According to the empirical results, the coefficient of financial development was positive for developed countries, but insignificant both in terms of statistics and economics. However, the coefficient of financial development was positive and significant at the $1 \%$ level for emerging market and developing countries, which was similar to the full sample regression. This indicated that the financial development has positive effect on carbon emissions in emerging market and developing countries, and had no obvious effect in developed countries.

This result may be explained by developed countries generally having well-developed industrial systems and strict environmental regulations. Therefore, enterprises tend to invest in technological innovation but not scale expansion, and the government prefers to support the development of green finance, which leads to more funding in environmental protection projects. Although the development of the financial sector also stimulates consumption, which can generate more emissions, these positive and negative effects tend to neutralize and eliminate the negative influence of financial development on carbon emissions.

Conversely, emerging market and developing countries often face tremendous pressure to develop economically, and the first priority is to increase output rather than environmental protection. The enterprises tend to expand production scale though credit rather than developing energy saving technology; therefore, the development of the financial sector could indirectly increase carbon emissions. The mitigation of financing the constraints of the consumers could also increase consumption and eventually enhance the positive effect of financial development.

These empirical results are similar with the works of Shahbaz et al. [22], Dogan and Turkekul [14] and Paramati et al. [28], which reflect the national difference of the effect of financial development on carbon emissions. 


\subsection{Results of Regressions with Different Proxy Variables of Financial Development}

The previous section analyzed the "aggregate" effect of financial development on carbon emissions with a comprehensive index proposed by Svirydzenka [41]. However, scholars commonly consider that financial development has rich connotation and can be further divided into different aspects, and the macro effect of financial development may vary if we focus on its different aspects. Therefore, in this section, we investigated the influence of different aspects of financial development on carbon emissions with a series of proxy variables of financial development, to detect the relationship of financial development and carbon emissions for a comprehensive angle, and to verify the reliability and accuracy of the previous empirical results.

The proxy variables of financial development used in this section were FD2-FD6. Generally, financial development is divided into the development of financial institution and the development of stock market (corresponding with indirect financing and direct financing respectively). We used FD2, FD3 and FD4 as the proxy variables of the development of financial institution, and FD5 and FD6 to be the proxy variables of the development of stock market. As the FD2, FD3, and FD4 indexes had a relatively adequate sample size, we not only estimated the full sample regression but also the sub-sample regressions when we used these three proxies. However, given the limited data availability, we only estimated the full sample regression when we used the FD5 and FD6 indexes. Tables 8-11 present the results of the regressions.

Table 8. Results of the full sample and sub-sample regressions (explanatory variables: financial development variable two, FD2).

\begin{tabular}{|c|c|c|c|}
\hline Variable & Full Sample & Developed Countries & $\begin{array}{l}\text { Emerging Market and } \\
\text { Developing Countries }\end{array}$ \\
\hline L.CE & $\begin{array}{c}0.7158688^{* * *} \\
(0.0535541)\end{array}$ & $\begin{array}{c}0.8430449 * * * \\
(0.1012896)\end{array}$ & $\begin{array}{c}0.6349239 * * * \\
(0.0691121)\end{array}$ \\
\hline FD2 & $\begin{array}{c}0.1589478^{* * *} \\
(0.0297083)\end{array}$ & $\begin{array}{c}0.0106708 \\
(0.0200120)\end{array}$ & $\begin{array}{c}0.2067815^{* * *} \\
(0.0403396)\end{array}$ \\
\hline TRADE & $\begin{array}{l}0.0610658 * \\
(0.0343227)\end{array}$ & $\begin{array}{l}-0.0020720 \\
(0.0262351)\end{array}$ & $\begin{array}{c}0.0903411 \\
(0.0567861)\end{array}$ \\
\hline URBAN & $\begin{array}{c}0.4440801^{* * *} \\
(0.0952552)\end{array}$ & $\begin{array}{c}0.0694749 \\
(0.0512456)\end{array}$ & $\begin{array}{c}0.5618609 * * * \\
(0.1139001)\end{array}$ \\
\hline POP & $\begin{array}{c}-0.0434512 \text { ** } \\
(0.0193565)\end{array}$ & $\begin{array}{c}0.0092695 \\
(0.0142356)\end{array}$ & $\begin{array}{c}-0.0555434 \\
(0.0264847)\end{array}$ \\
\hline IND & $\begin{array}{c}0.1977202^{* * *} \\
(0.0497561)\end{array}$ & $\begin{array}{c}0.0905716 \\
(0.0730781)\end{array}$ & $\begin{array}{c}0.2278650^{* * * *} \\
(0.0742844)\end{array}$ \\
\hline Constant & $\begin{array}{c}-2.9381255^{* * *} \\
(0.5697875)\end{array}$ & $\begin{array}{l}-0.3130130 \\
(0.2920472)\end{array}$ & $\begin{array}{c}-3.7340408^{* * *} \\
(0.7032304)\end{array}$ \\
\hline No. countries & 155 & 35 & 120 \\
\hline AR (1) & $\begin{array}{c}-5.89 * * * \\
(0.000)\end{array}$ & $\begin{array}{c}-3.11 * * * \\
(0.002)\end{array}$ & $\begin{array}{c}-5.07^{* * *} \\
(0.000)\end{array}$ \\
\hline AR (2) & $\begin{array}{c}-0.07 \\
(0.948)\end{array}$ & $\begin{array}{c}-0.29 \\
(0.773)\end{array}$ & $\begin{array}{c}0.02 \\
(0.982)\end{array}$ \\
\hline Hansen test & $\begin{array}{l}144.81 \\
(0.210)\end{array}$ & $\begin{array}{c}30.40 \\
(0.138)\end{array}$ & $\begin{array}{l}104.01 \\
(0.166)\end{array}$ \\
\hline
\end{tabular}

Note: ${ }^{* * *}, * *$, and ${ }^{*}$ indicate significance at $1 \%, 5 \%$, and $10 \%$ levels, respectively. 
Table 9. Results of the full sample and sub-sample regressions (explanatory variables: FD3).

\begin{tabular}{|c|c|c|c|}
\hline Variable & Full Sample & $\begin{array}{l}\text { Developed } \\
\text { Countries }\end{array}$ & $\begin{array}{l}\text { Emerging Market and } \\
\text { Developing Countries }\end{array}$ \\
\hline L.CE & $\begin{array}{c}0.7317546^{* * *} \\
(0.0543573) \\
\end{array}$ & $\begin{array}{c}0.8479038^{* * *} \\
(0.0896954)\end{array}$ & $\begin{array}{c}0.6552704^{* * *} \\
(0.0684584)\end{array}$ \\
\hline FD3 & $\begin{array}{l}0.1519494^{* * *} \\
(0.0306952)\end{array}$ & $\begin{array}{l}-0.0474410 \\
(0.0463207)\end{array}$ & $\begin{array}{c}0.1874231^{* * * *} \\
(0.0390445)\end{array}$ \\
\hline TRADE & $\begin{array}{l}0.0893570 * * * \\
(0.0325994)\end{array}$ & $\begin{array}{c}0.0655369 \\
(0.0763839)\end{array}$ & $\begin{array}{l}0.1328738 * * \\
(0.0541487)\end{array}$ \\
\hline URBAN & $\begin{array}{c}0.4296097^{* * *} \\
(0.0968563)\end{array}$ & $\begin{array}{c}0.0700011 \\
(0.1447222)\end{array}$ & $\begin{array}{c}0.5160384^{* * *} \\
(0.1129521)\end{array}$ \\
\hline POP & $\begin{array}{c}-0.0321672 * \\
(0.0176906)\end{array}$ & $\begin{array}{l}-0.0128571 \\
(0.0190466) \\
\end{array}$ & $\begin{array}{c}-0.0457082 * \\
(0.0250292)\end{array}$ \\
\hline IND & $\begin{array}{l}0.1799730^{* * *} \\
(0.0529909)\end{array}$ & $\begin{array}{c}0.1900178 \\
(0.1325729)\end{array}$ & $\begin{array}{c}0.2345657^{* * *} \\
(0.0752635)\end{array}$ \\
\hline Constant & $\begin{array}{c}-2.9999570 * * * \\
(0.6089951)\end{array}$ & $\begin{array}{l}-0.6338886 \\
(1.1928016)\end{array}$ & $\begin{array}{c}-3.7893095^{* * *} \\
(0.7315792)\end{array}$ \\
\hline No. countries & 147 & 28 & 119 \\
\hline AR (1) & $\begin{array}{l}-5.64^{* * *} \\
(0.000)\end{array}$ & $\begin{array}{l}-2.45^{* *} \\
(0.014)\end{array}$ & $\begin{array}{l}-5.12^{* * *} \\
(0.000)\end{array}$ \\
\hline AR (2) & $\begin{array}{c}-1.01 \\
(0.311)\end{array}$ & $\begin{array}{c}-1.12 \\
(0.262)\end{array}$ & $\begin{array}{l}-0.83 \\
(0.406)\end{array}$ \\
\hline Hansen test & $\begin{array}{l}142.65 \\
(0.248)\end{array}$ & $\begin{array}{c}25.45 \\
(0.185)\end{array}$ & $\begin{array}{l}101.37 \\
(0.215)\end{array}$ \\
\hline
\end{tabular}

Note: ${ }^{* * *}, * *$, and ${ }^{*}$ indicate significance at $1 \%, 5 \%$, and $10 \%$ levels, respectively.

Table 10. Results of the full sample and sub-sample regressions (explanatory variables: FD4).

\begin{tabular}{cccc}
\hline Variable & Full Sample & Developed Countries & $\begin{array}{c}\text { Emerging Market and } \\
\text { Developing Countries }\end{array}$ \\
\hline \multirow{2}{*}{ L.CE } & $\begin{array}{c}0.6721688^{* * *} \\
(0.0631201)\end{array}$ & $\begin{array}{c}0.7831462^{* * *} \\
(0.0913885)\end{array}$ & $\begin{array}{c}0.6289033^{* * *} \\
(0.0703863)\end{array}$ \\
\hline \multirow{2}{*}{ FD4 } & $0.1702764^{* * *}$ & 0.0089098 & $0.1872831^{* * *}$ \\
& $(0.0340425)$ & $(0.0557672)$ & $(0.0375433)$ \\
\hline \multirow{2}{*}{ TRADE } & $0.0677760^{*}$ & 0.0217901 & $0.1009734^{*}$ \\
& $(0.0360426)$ & $(0.0933853)$ & $(0.0562001)$ \\
\hline \multirow{2}{*}{ URBAN } & $0.5187499^{* * *}$ & 0.1714139 & $0.5778977^{* * *}$ \\
& $(0.1166181)$ & $(0.1330308)$ & $(0.1218666)$ \\
\hline \multirow{2}{*}{ POP } & $-0.0437665^{*}$ & 0.0000919 & $-0.0518710^{* *}$ \\
& $(0.0226795)$ & $(0.0176074)$ & $(0.0262629)$ \\
\hline \multirow{2}{*}{ IND } & $0.1997536^{* * *}$ & $0.2439661^{* *}$ & $0.2122822^{* * *}$ \\
& $(0.0556928)$ & $(0.1035543)$ & $(0.0819533)$ \\
\hline \multirow{2}{*}{ Constant } & $-3.2648075^{* * *}$ & -1.1937344 & $-3.7016372^{* * *}$ \\
& $(0.6613276)$ & $(0.9307830)$ & $(0.7736308)$ \\
\hline
\end{tabular}


Table 10. Cont.

\begin{tabular}{cccc}
\hline Variable & Full Sample & Developed Countries & $\begin{array}{c}\text { Emerging Market and } \\
\text { Developing Countries }\end{array}$ \\
\hline No. countries & 139 & 29 & 110 \\
\hline \multirow{2}{*}{ AR (1) } & $-5.19^{* * *}$ & $-2.64 * * *$ & $-4.75^{* * *}$ \\
& $(0.000)$ & $(0.008)$ & $(0.000)$ \\
\hline \multirow{2}{*}{ AR (2) } & -0.39 & -0.51 & -0.33 \\
& $(0.696)$ & $(0.612)$ & $(0.744)$ \\
\hline \multirow{2}{*}{ Hansen test } & 127.65 & 25.50 & 96.72 \\
& $(0.148)$ & $(0.183)$ & $(0.321)$ \\
\hline
\end{tabular}

Note: ${ }^{* *}, * *$, and $*$ indicate significance at $1 \%, 5 \%$, and $10 \%$ levels, respectively.

Table 11. Results of the full sample regressions (explanatory variables: FD5 and FD6).

\begin{tabular}{ccc}
\hline Variable & FD5 & FD6 \\
\hline \multirow{2}{*}{ L.CE } & $0.4636904^{* * *}$ & $0.6942905^{* * *}$ \\
& $(0.1447732)$ & $(0.0726658)$ \\
\hline \multirow{2}{*}{ FD5/FD6 } & $0.0492784^{* * *}$ & $0.0785047^{* * *}$ \\
& $(0.0173954)$ & $(0.0258335)$ \\
\hline TRADE & $0.1550326^{* *}$ & $0.0916717^{*}$ \\
& $(0.0677723)$ & $(0.0529239)$ \\
\hline URBAN & $0.9723596^{* * *}$ & 0.2732316 \\
& $(0.3228306)$ & $(0.2332033)$ \\
\hline \multirow{2}{*}{ POP } & $-0.0794701^{* *}$ & $-0.0627705^{* *}$ \\
& $(0.0383007)$ & $(0.0297382)$ \\
\hline IND & 0.20759 & $0.2250498^{* *}$ \\
& $(0.1451585)$ & $(0.1007877)$ \\
\hline \multirow{2}{*}{ Constant } & $-4.621357^{* * *}$ & $-2.033003^{* *}$ \\
\hline Number of countries & $(1.396115)$ & $(0.9811004)$ \\
\hline \multirow{2}{*}{ AR (1) } & 60 & 48 \\
\hline \multirow{2}{*}{ AR (2) } & $-2.47^{* * *}$ & $(0.000)$ \\
\hline \multirow{2}{*}{ Hansen test } & $(0.013)$ & -1.07 \\
& -1.02 & $(0.285)$ \\
\hline
\end{tabular}

Note: ${ }^{* *}, * *$, and ${ }^{*}$ indicate significance at $1 \%, 5 \%$, and $10 \%$ levels, respectively.

Tables 8-10 show that the coefficients of FD2, FD3, and FD4 for the full sample regressions were $0.1589478,0.1519494$, and 0.1702764 , respectively, and were significant at the $1 \%$ level. For the sub-sample regressions in Tables 8-10, the coefficients of developed countries were all small and insignificant, and the coefficients of emerging market and developing countries were all positive and significant at the $1 \%$ level. In addition, Table 11 shows that the coefficients of FD5 and FD6 were 0.0492784 and 0.0785047 , respectively, which were significant at the $1 \%$ level.

By comparing the values of coefficients of FD2-6, we can readily notice that for FD2-4 and FD5-6 respectively, they were quite close with each other while the coefficients of FD2-4 were evidently larger than FD5-6, which implied that the development of financial institution had greater influence on carbon emissions than the development of the stock market (it was reasonable to believe this conclusion was reliable as we adopted more than one proxy variables for each aspect). This may have been caused by the following reasons: the stock market allows listed companies to access an 
additional source of equity financing besides the debt financing, which leads to the consumption of more energy by stimulating the growth of business, and finally contributes to the increase of carbon emissions, however, the listed companies are strictly supervised by the financial authorities and the public, therefore they will emphasize the social responsibility of environmental protection and utilize more advanced technologies which could increase the energy efficiency and reduce carbon emissions. To the contrary, the companies acquire their loans mainly from financial institutions not subject to these limitations and consequently have less motivation on environmental protection during their productive activities. Therefore, the coefficients of FD5-6 which represent the development of the stock market, were relatively smaller compared with FD2-4 which represent the development of financial institution.

In addition, these empirical results also have the following implications: (1) while we divided the financial development into two aspects by adopting other five proxy variables, all of their coefficients were significantly positive, which were inconsistent with the result of regression using the index of FD1, this further proved that the financial development could significantly increase carbon emissions from the global perspective; (2) the results of sub-sample regressions in Tables 8-10 indicated that the financial development has no obvious effect on carbon emissions while it has a positive effect on carbon emissions in the emerging market and developing countries, which further proved the conclusion of the sub-sample regressions with FD1.

\section{Robustness Checks}

The previous empirical analysis proved that financial development can increase carbon emissions from a global perspective, in this section, we conducted two robustness checks to verify the reliability of the above empirical results.

\subsection{Different Estimation Methods}

We chose the system GMM to estimate the models because it could effectively cope with the endogenous problems of a dynamic panel. In this section, we adopted a static panel and the traditional estimation strategies, which include the pooled OLS, fixed effect (FE), and random effect (RE) to examine the influence of financial development on carbon emissions and the robustness of our empirical results.

Table 12 presents the estimation results of the static panel model. All the coefficients of FD1 were significant at the $1 \%$ level, which was consistent with the previous results. The Hausman test indicated that the fixed effect was better than the random effect model; however, we reported both of the results, which were quite similar. These empirical results proved that our conclusions were consistent under different model specifications, and further indicated that our model might not seriously suffer from the issue of endogeneity, as we could notice the value of coefficients estimated by the fixed effect, random effect and GMM were quite similar. As we know, the issue of endogeneity is generally caused by the existence of reverse causality, however the above analysis indicated that the reverse causality might not exist in the relationship of financial development and carbon emissions. This is consistent with most works of scholars, as very little research has reported the appearance of reverse causality on it.

Table 12. Results of the static panel regressions.

\begin{tabular}{cccc}
\hline Variable & Pooled OLS & Fixed Effect & Random Effect \\
\hline \multirow{2}{*}{ FD1 } & $2.6474191^{* * *}$ & $0.4073476^{* * *}$ & $0.5058472^{* * *}$ \\
& $(0.0760941)$ & $(0.0635407)$ & $(0.0638911)$ \\
\hline \multirow{2}{*}{ TRADE } & $0.3645025^{* * *}$ & 0.0092904 & 0.0044025 \\
& $(0.0209273)$ & $(0.0168561)$ & $(0.0169482)$ \\
\hline \multirow{2}{*}{ URBAN } & $1.4861864^{* * *}$ & $1.2674027^{* * *}$ & $1.3752265^{* * *}$ \\
& $(0.0338968)$ & $(0.0448558)$ & $(0.0434128)$ \\
\hline
\end{tabular}


Table 12. Cont.

\begin{tabular}{cccc}
\hline Variable & Pooled OLS & Fixed Effect & Random Effect \\
\hline \multirow{2}{*}{ POP } & $-0.2018761^{* * *}$ & $-0.0214406^{* * *}$ & $-0.0258266^{* * *}$ \\
& $(0.0097875)$ & $(0.0051369)$ & $(0.0052231)$ \\
\hline \multirow{2}{*}{ IND } & $0.6594443^{* * *}$ & $0.2317015^{* * *}$ & $0.2462267^{* * *}$ \\
& $(0.0333297)$ & $(0.0217389)$ & $(0.0220302)$ \\
\hline \multirow{2}{*}{ Constant } & $-9.4038995^{* * *}$ & $-5.2551822^{* * *}$ & $-5.7234972^{* * *}$ \\
& $(0.1475040)$ & $(0.1774299)$ & $(0.1832383)$ \\
\hline No. countries & 155 & 155 & 155 \\
\hline \multicolumn{2}{c}{ Note: ${ }^{* * *},{ }^{* *}$, and $^{*}$ indicate significance at $1 \%, 5 \%$, and $10 \%$ levels, respectively. }
\end{tabular}

\subsection{Longer Sample Periods}

When we adopted the panel data analysis, we often had to balance the number and the period of the sample data, as they generally appeared to have a negative correlation. In our main regression, we chose the panel data of 155 countries from 1990 to 2014, as we thought that this would be the best sample size for our analysis according to the data characteristics. We attempted to analyze the relationship between financial development and carbon emissions from the perspective of a longer time dimension by extending the sample period. This lost more sample countries but allowed us to examine whether the above conclusions were valid in the long-term.

Specifically, according to the data availability, we extended the sample period of our main model to 1980-2014. As the FD2 index had relatively complete data compared with other indexes in the earlier years, we used FD2 as the proxy of financial development and extended the initial sample period from 1990 to 1980,1970 , and, 1960, separately.

Table 13 shows that the coefficients of FD1 and FD2 were all positive and strongly significant, which implied that the previous results were valid in the long-term. We estimated the first three regressions with the same system GMM; however, we estimated the last regression (FD2, 1960-2014) using the least squares dummy variable corrected (LSDVC) method, as the sample data of this regression were long panel data (the number of years was larger than the number of countries); therefore, the estimated values would have appeared to have a serious bias if we used GMM. LSDVC performs much better than GMM under this circumstance [56,57].

Table 13. Results of the full sample regressions with longer periods.

\begin{tabular}{|c|c|c|c|c|}
\hline & FD1 & & FD2 & \\
\hline Variable & 1980-2014 & 1980-2014 & 1970-2014 & 1960-2014 \\
\hline L.CE & $\begin{array}{c}0.4839347^{* * * *} \\
(0.1067562)\end{array}$ & $\begin{array}{c}0.43838722^{* * *} \\
(0.1034471)\end{array}$ & $\begin{array}{c}0.7236401^{* * *} \\
(0.0732967)\end{array}$ & $\begin{array}{c}0.884147^{* * *} \\
(0.00817)\end{array}$ \\
\hline FD1/FD2 & $\begin{array}{c}1.6262826^{* * * *} \\
(0.3733870)\end{array}$ & $\begin{array}{c}0.3344634^{* * *} \\
(0.0744378)\end{array}$ & $\begin{array}{c}0.1983611^{* * *} \\
(0.0679762)\end{array}$ & $\begin{array}{c}0.0323547^{* * *} \\
(0.0102972)\end{array}$ \\
\hline TRADE & $\begin{array}{c}0.1824042^{* * * *} \\
(0.0658842)\end{array}$ & $\begin{array}{c}0.126911 \\
(0.0793001)\end{array}$ & $\begin{array}{c}0.0421382 \\
(0.0570367)\end{array}$ & $\begin{array}{c}0.0560654^{* * *} \\
(0.0143864)\end{array}$ \\
\hline URBAN & $\begin{array}{c}0.6113399 * * * \\
(0.1382679)\end{array}$ & $\begin{array}{c}0.6844983^{* * *} \\
(0.1324414)\end{array}$ & $\begin{array}{c}0.1865905 \\
(0.1533993)\end{array}$ & $\begin{array}{c}0.0215443 \\
(0.0183576)\end{array}$ \\
\hline POP & $\begin{array}{c}-0.0870749^{* * *} \\
(0.0282710)\end{array}$ & $\begin{array}{c}-0.0605956 * \\
(0.0335829)\end{array}$ & $\begin{array}{l}-0.0200851 \\
(0.0199274)\end{array}$ & $\begin{array}{c}-0.0012604 \\
(0.008534)\end{array}$ \\
\hline IND & $\begin{array}{c}0.3701238^{* * * *} \\
(0.0960192)\end{array}$ & $\begin{array}{c}0.4382745^{* * *} \\
(0.1244763)\end{array}$ & $\begin{array}{c}0.1286947 \\
(0.1215409)\end{array}$ & $\begin{array}{c}0.0285649 * * * \\
(0.010906)\end{array}$ \\
\hline Constant & $\begin{array}{c}-4.4280447^{* * *} \\
(0.9307957)\end{array}$ & $\begin{array}{c}-5.436065^{* * *} \\
(1.070145)\end{array}$ & $\begin{array}{c}-1.887942^{* * *} \\
(0.5800526)\end{array}$ & - \\
\hline
\end{tabular}


Table 13. Cont.

\begin{tabular}{ccccc}
\hline & FD1 & \multicolumn{3}{c}{ FD2 } \\
\hline Variable & $\mathbf{1 9 8 0 - 2 0 1 4}$ & $\mathbf{1 9 8 0 - 2 0 1 4}$ & $\mathbf{1 9 7 0 - 2 0 1 4}$ & $\mathbf{1 9 6 0 - 2 0 1 4}$ \\
\hline No. countries & 90 & 81 & 58 & 41 \\
\hline \multirow{2}{*}{ AR (1) } & $-3.75^{* * *}$ & $-3.39 * * *$ & $-3.79 * * *$ & - \\
& $(0.000)$ & $(0.001)$ & $(0.000)$ & - \\
\multirow{2}{*}{ AR (2) } & -0.40 & -1.09 & -1.25 & - \\
\hline \multirow{2}{*}{ Hansen test } & $(0.688)$ & $(0.277)$ & $(0.213)$ & \\
& 73.58 & 71.15 & $(0.423)$ & \\
\hline
\end{tabular}

Note: ${ }^{* *},{ }^{* *}$, and ${ }^{*}$ indicate significance at $1 \%, 5 \%$, and $10 \%$ levels, respectively.

\section{Discussion}

As most of research on the relationship between financial development and carbon emissions focuses on specific countries or regions, our study analyzed their relationship from the global perspective with worldwide cross-country panel data, and investigated the national difference by dividing the country samples into two sub-groups, besides, we further examined the effect of different aspects of financial development on carbon emissions with a series proxy variables, under a unified framework. Therefore, compared with the previous research, our study could provide a macroscopic intuition and more empirical evidence on this topic. Although our conclusions were consistent with some research $[22,23,28]$, they were quite different from other works $[16,17,27]$. As mentioned above, the controversial conclusions reflect the complexity of the relationship between financial development and carbon emissions, which may vary across countries or regions, therefore it is unreasonable to hold a constant opinion, and additional in-depth research is needed on this topic.

The main limitation of our research was, we investigated the national difference of the effect of financial development on carbon emissions by dividing the country samples into two sub-groups, however, due to the inadequate data and the lack of relevant research, we could not conduct more accurate analysis on it. Specifically, the controversial results obtained by research on this topic (including our study) actually reflected the nonlinear characteristics of the relationship between financial development and carbon emissions to some extent. In other words, there might exist one or more factors which could significantly affect the relationship between financial development and carbon emissions. These factors could be concrete ones such as institution and policy, or a general concept such as income level or development level of a country. This might be an interesting and worthwhile research direction that scholars have rarely focused on.

\section{Conclusions and Policy Implications}

In this study, we empirically researched the relationship between financial development and carbon emissions based on the data of 155 countries, and analyzed the national differences by dividing the sample countries into two sub-groups: developed countries, and emerging market and developing countries. Besides, we further investigated the effect of different aspects of financial development on carbon emissions by adopting a series of proxy variables. According to the empirical results, we concluded that the financial development can increase carbon emissions from a global perspective, and this conclusion remains valid for the sub-group of emerging market and developing countries. However, the empirical results indicated that financial development has no obvious influence on carbon emissions for developed countries. Besides, compared with the development of stock market, the development of financial institution has a relatively stronger effect on carbon emissions. The robustness checks proved that the above empirical results are reliable.

The empirical analysis suggests the following policy implications: 
(1) Over the past few decades, the growing carbon emissions have become a global environmental issue which received widespread attention. According to the data of World Bank, the world's metric tons per capita carbon emissions is 4.19 in 1990, but dramatically increased to 4.97 in 2014. Although some research considers that the financial development could reduce carbon emissions and find empirical evidence in several countries or regions $[9,15,16]$, our analysis indicated that the financial development has a positive effect on carbon emissions from the global perspective, which means the development of the financial sector cannot be intuitively deemed as a measure to address environmental degradation, and policymakers should carefully analyze the environmental effects of financial development and balance this relationship based on specific circumstances of a country.

(2) The empirical results of the sub-groups indicated that in emerging market and developing countries, the financial development has a positive effect on carbon emissions while it has no obvious influence in developed countries. These are consistent with the conclusions of some research [14,23,28]. This implies that with the increase in the development level of a country, the "positive effect" of financial development on carbon emissions will be gradually offset by the "negative effect".

Generally, the developed countries have well-developed industrial systems that enterprises tend to invest in technological innovation but not scale expansion, and the financial sectors prefer to fund for environmental protection projects due to the strict environmental regulations of government. These could largely neutralize the "positive effect" of financial development. Consequently, policymakers in developed countries are not facing environmental pressure while planning the development of the financial sector, which will enable them to concentrate on the function of resource allocation and growth effect of financial development.

Nevertheless, due to the undeveloped industrial sectors and the pressure of economic development in emerging and developing countries, the enterprises tend to expand production scale though credit rather than developing energy saving technology, hence the "positive effect" of financial development dominates and the development of financial sector has a significant effect on carbon emissions. This reflects the unavoidable contradiction of economic development and environmental protection. Notwithstanding, we suggest the policymakers in emerging and developing countries to carefully balance their relationship and attach importance to emission reduction, as the extensive growth will conversely impede the long-run economic development, meanwhile, it will dramatically increase the cost of environmental pollution control in the future. Specifically, it might be reasonable for governments to lead more financial resources for industrial upgrading, which could improve production and energy efficiency and finally promote economic growth from the channel of total factor productivity (TFP) [58], along with the reduction of carbon emissions.

In addition, the empirical results of the sub-groups also implied that the influence of financial development on carbon emissions might agree with the law of short-term pain, long-term gain, from the macro perspective. Therefore, policymakers in emerging market and developing countries could comprehensively regard the positive effect of financial development, and formulate a long-term strategy for the domestic development of the financial sector.

(3) The empirical results of regressions with different proxy variables of financial development reflected that the development of stock market has obviously smaller influence on carbon emissions than the development of financial institution. This may be caused by the strict supervision of listed companies which enforce them to assume social responsibility of environmental protection and utilize more advanced technologies which could increase the energy efficiency and reduce carbon emissions. Therefore, the authorities might consider giving a priority for the development of the stock market, as it performs better to limit the increase of carbon emissions, compared with the development of financial institution.

Author Contributions: Conceptualization, C.J. and X.M.; data curation, X.M.; formal analysis, C.J. and X.M.; funding acquisition, C.J.; investigation, X.M.; methodology, C.J. and X.M.; project administration, C.J.; resources, X.M.; software, X.M.; supervision, C.J. and X.M.; validation, X.M.; visualization, X.M.; writing一 original draft, X.M.; writing-review and editing, C.J. and X.M. 
Funding: This research was funded by the Chinese National Funding of Social Sciences, Grant Number 15ZDC020. The APC was funded by the Chinese National Funding of Social Sciences.

Conflicts of Interest: The authors declare no conflict of interest.

\section{Appendix A Sample Countries and Classification}

We expanded our country sample to the utmost extent in order to enhance the reliability of empirical results. However, we had to drop several countries due to the significant missing data and obtained a sample of 155 countries. Table A1 presents the sample countries by different groups.

Table A1. Sample countries and classification.

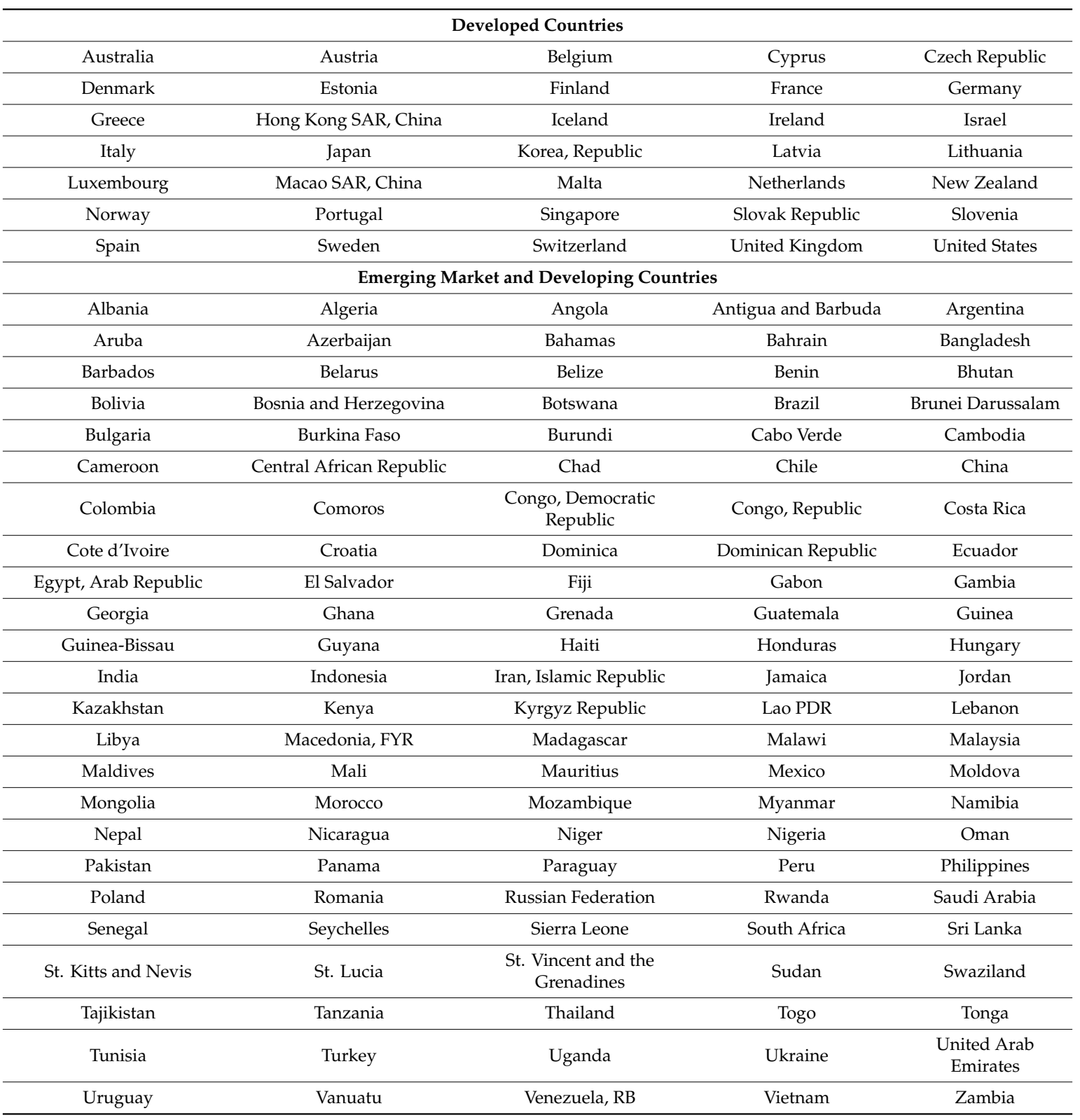

In order to study the country specific effect of the influence of financial development on carbon emissions, we divided the sample into two groups, namely developed countries and emerging market and developing countries, this is based on the country classification of International Monetary Fund (IMF) [59]. Compared with other classification criterion, the characteristics of different types of countries was comprehensively considered rather than a single aspect or indicator, and it has been 
widely adopted in empirical research, such as von Hagen and Zhou [29], Donadelli and Paradiso [30], and Wu et al. [31].

It is necessary to explain that we used the word "country" in this article for simplicity, actually it refers to "country and region", which included special administrative regions et al.

\section{Appendix B The Introduction of the Index Proposed by Svirydzenka (2016) (FD1)}

We used the comprehensive index of financial development proposed by Svirydzenka [41], to be one of the proxy variables of financial development. This index is constructed using six sub-indexes, concerning the depth, access, and efficiency of financial institutions and markets. Table A2 presents the framework of this index.

Table A2. Framework of the index proposed by Svirydzenka [41] (FD1).

\begin{tabular}{ccc}
\hline Aggregate Index & First-Level Sub-Index & Second-Level Sub-Index \\
\hline & Financial Institutions & Depth (FID) \\
\cline { 3 - 3 } $\begin{array}{c}\text { Financial Development } \\
\text { (FD) }\end{array}$ & Access (FIA) \\
\cline { 2 - 3 } & Financial Markets & Efficiency (FIE) \\
\cline { 2 - 3 } & $(\mathrm{FM})$ & Depth (FME) \\
\hline
\end{tabular}

Source: IMF website [60].

Svirydzenka [41] divided financial development into two aspects: financial institutions and financial markets, then measuring each aspect from the angles of depth, access, and efficiency. By adopting a series of original indexes and methodologies, the author first computed two first-level sub-indexes, namely financial institutions and financial markets, then computed the aggregate index-financial development based on the first-level sub-indexes. Due to the length limitation, we do not further introduce the detailed construction process of this index, please refer to the original manuscript of Svirydzenka [41] for the complete information. The data of index can be extracted from the website of the IMF [60].

\section{References}

1. Grossman, G.M.; Krueger, A.B. Economic-Growth and the Environment. Q. J. Econ. 1995, 110, $353-377$. [CrossRef]

2. Arouri, M.E.; Ben Youssef, A.; M'Henni, H.; Rault, C. Energy consumption, economic growth and $\mathrm{CO}_{2}$ emissions in Middle East and North African countries. Energy Policy 2012, 45, 342-349. [CrossRef]

3. Ozturk, I.; Al-Mulali, U.; Saboori, B. Investigating the environmental Kuznets curve hypothesis: The role of tourism and ecological footprint. Environ. Sci. Pollut. Res. 2016, 23, 1916-1928. [CrossRef] [PubMed]

4. Zaman, K.; Shahbaz, M.; Loganathan, N.; Raza, S.A. Tourism development, energy consumption and Environmental Kuznets Curve: Trivariate analysis in the panel of developed and developing countries. Tour. Manag. 2016, 54, 275-283. [CrossRef]

5. Harbaugh, W.T.; Levinson, A.; Wilson, D.M. Reexamining the empirical evidence for an environmental Kuznets curve. Rev. Econ. Stat. 2002, 84, 541-551. [CrossRef]

6. Farhani, S.; Ozturk, I. Causal relationship between $\mathrm{CO}_{2}$ emissions, real GDP, energy consumption, financial development, trade openness, and urbanization in Tunisia. Environ. Sci. Pollut. Res. 2015, 22, 15663-15676. [CrossRef]

7. Sterpu, M.; Soava, G.; Mehedintu, A. Impact of Economic Growth and Energy Consumption on Greenhouse Gas Emissions: Testing Environmental Curves Hypotheses on EU Countries. Sustainability 2018, 10, 14. [CrossRef] 
8. Tamazian, A.; Chousa, J.P.; Vadlamannati, K.C. Does higher economic and financial development lead to environmental degradation: Evidence from BRIC countries. Energy Policy 2009, 37, 246-253. [CrossRef]

9. Shahbaz, M.; Tiwari, A.K.; Nasir, M. The effects of financial development, economic growth, coal consumption and trade openness on $\mathrm{CO}_{2}$ emissions in South Africa. Energy Policy 2013, 61, 1452-1459. [CrossRef]

10. Dasgupta, S.; Laplante, B.; Mamingi, N. Pollution and capital markets in developing countries. J. Environ. Econ. Manag. 2001, 42, 310-335. [CrossRef]

11. Islam, F.; Shahbaz, M.; Ahmed, A.U.; Alam, M.M. Financial development and energy consumption nexus in Malaysia: A multivariate time series analysis. Econ. Model. 2013, 30, 435-441. [CrossRef]

12. Sadorsky, P. The impact of financial development on energy consumption in emerging economies. Energy Policy 2010, 38, 2528-2535. [CrossRef]

13. Zhang, Y.J. The impact of financial development on carbon emissions: An empirical analysis in China. Energy Policy 2011, 39, 2197-2203. [CrossRef]

14. Dogan, E.; Turkekul, B. $\mathrm{CO}_{2}$ emissions, real output, energy consumption, trade, urbanization and financial development: Testing the EKC hypothesis for the USA. Environ. Sci. Pollut. Res. 2016, 23, 1203-1213. [CrossRef] [PubMed]

15. Tamazian, A.; Rao, B.B. Do economic, financial and institutional developments matter for environmental degradation? Evidence from transitional economies. Energy Econ. 2010, 32, 137-145. [CrossRef]

16. Saidi, K.; Ben Mbarek, M. The impact of income, trade, urbanization, and financial development on $\mathrm{CO}_{2}$ emissions in 19 emerging economies. Environ. Sci. Pollut. Res. 2017, 24, 12748-12757. [CrossRef] [PubMed]

17. Omri, A.; Daly, S.; Rault, C.; Chaibi, A. Financial development, environmental quality, trade and economic growth: What causes what in MENA countries. Energy Econ. 2015, 48, 242-252. [CrossRef]

18. Dogan, E.; Seker, F. The influence of real output, renewable and non-renewable energy, trade and financial development on carbon emissions in the top renewable energy countries. Renew. Sustain. Energy Rev. 2016, 60, 1074-1085. [CrossRef]

19. Zaidi, S.A.H.; Zafar, M.W.; Shahbaz, M.; Hou, F.J. Dynamic linkages between globalization, financial development and carbon emissions: Evidence from Asia Pacific Economic Cooperation countries. J. Clean. Prod. 2019, 228, 533-543. [CrossRef]

20. Zafar, M.W.; Saud, S.; Hou, F.J. The impact of globalization and financial development on environmental quality: Evidence from selected countries in the Organization for Economic Co-operation and Development (OECD). Environ. Sci. Pollut. Res. 2019, 26, 13246-13262. [CrossRef]

21. Al-Mulali, U.; Ozturk, I.; Lean, H.H. The influence of economic growth, urbanization, trade openness, financial development, and renewable energy on pollution in Europe. Nat. Hazards 2015, 79, 621-644. [CrossRef]

22. Shahbaz, M.; Shahzad, S.J.H.; Ahmad, N.; Alam, S. Financial development and environmental quality: The way forward. Energy Policy 2016, 98, 353-364. [CrossRef]

23. Bekhet, H.A.; Matar, A.; Yasmin, T. $\mathrm{CO}_{2}$ emissions, energy consumption, economic growth, and financial development in GCC countries: Dynamic simultaneous equation models. Renew. Sustain. Energy Rev. 2017, 70, 117-132. [CrossRef]

24. Lu, W.C. The impacts of information and communication technology, energy consumption, financial development, and economic growth on carbon dioxide emissions in 12 Asian countries. Mitig. Adapt. Strateg. Glob. Chang. 2018, 23, 1351-1365. [CrossRef]

25. Cetin, M.; Ecevit, E.; Yucel, A.G. The impact of economic growth, energy consumption, trade openness, and financial development on carbon emissions: Empirical evidence from Turkey. Environ. Sci. Pollut. Res. 2018, 25, 36589-36603. [CrossRef]

26. Ali, H.S.; Law, S.H.; Lin, W.L.; Yusop, Z.; Chin, L.; Bare, U.A.A. Financial development and carbon dioxide emissions in Nigeria: Evidence from the ARDL bounds approach. GeoJournal 2019, 84, 641-655. [CrossRef]

27. Charfeddine, L.; Kahia, M. Impact of renewable energy consumption and financial development on $\mathrm{CO}_{2}$ emissions and economic growth in the MENA region: A panel vector autoregressive (PVAR) analysis. Renew. Energy 2019, 139, 198-213. [CrossRef]

28. Paramati, S.R.; Alam, M.S.; Apergis, N. The role of stock markets on environmental degradation: A comparative study of developed and emerging market economies across the globe. Emerg. Mark. Rev. 2018, 35, 19-30. [CrossRef] 
29. Von Hagen, J.; Zhou, J. The choice of exchange rate regimes in developing countries: A multinormal panel. J. Int. Money Financ. 2007, 26, 1071-1094. [CrossRef]

30. Donadelli, M.; Paradiso, A. Is there heterogeneity in financial integration dynamics? Evidence from country and industry emerging market equity indexes. J. Int. Financ. Mark. Inst. Money 2014, 32, 184-218. [CrossRef]

31. Wu, Y.; Zhu, Q.W.; Zhu, B.Z. Comparisons of decoupling trends of global economic growth and energy consumption between developed and developing countries. Energy Policy 2018, 116, 30-38. [CrossRef]

32. Arellano, M.; Bond, S. Some Tests of Specification for Panel Data-Monte-Carlo Evidence and An Application to Employment Equations. Rev. Econ. Stud. 1991, 58, 277-297. [CrossRef]

33. Arellano, M.; Bover, O. Another Look at the Instrumental Variable Estimation of Error-Components Models. J. Econom. 1995, 68, 29-51. [CrossRef]

34. Blundell, R.; Bond, S. Initial conditions and moment restrictions in dynamic panel data models. J. Econom. 1998, 87, 115-143. [CrossRef]

35. Roodman, D. How to do xtabond2: An introduction to difference and system GMM in Stata. Stata J. 2009, 9, 86-136. [CrossRef]

36. Halkos, G.E.; Polemis, M.L. Does Financial Development Affect Environmental Degradation? Evidence from the OECD Countries. Bus. Strategy Environ. 2017, 26, 1162-1180. [CrossRef]

37. Dutta, N.; Sobel, R.S. Entrepreneurship and human capital: The role of financial development. Int. Rev. Econ. Financ. 2018, 57, 319-332. [CrossRef]

38. Sobiech, I. Remittances, finance and growth: Does financial development foster the impact of remittances on economic growth? World Dev. 2019, 113, 44-59. [CrossRef]

39. Bayar, Y.; Gavriletea, M.D.; Ucar, Z. Financial Sector Development, Openness, and Entrepreneurship: Panel Regression Analysis. Sustainability 2018, 10, 11. [CrossRef]

40. Yang, F. The impact of financial development on economic growth in middle-income countries. J. Int. Financ. Mark. Inst. Money 2019, 59, 74-89. [CrossRef]

41. Svirydzenka, K. Introducing a New Broad-Based Index of Financial Development; IMF Working Paper; WP/16/5; International Monetary Fund: Washington, DC, USA, 2016; pp. 1-42.

42. Salahuddin, M.; Gow, J.; Ozturk, I. Is the long-run relationship between economic growth, electricity consumption, carbon dioxide emissions and financial development in Gulf Cooperation Council Countries robust? Renew. Sustain. Energy Rev. 2015, 51, 317-326. [CrossRef]

43. Li, S.S.; Zhang, J.L.; Ma, Y. Financial Development, Environmental Quality and Economic Growth. Sustainability 2015, 7, 9395-9416. [CrossRef]

44. Charfeddine, L.; Ben Khediri, K. Financial development and environmental quality in UAE: Cointegration with structural breaks. Renew. Sustain. Energy Rev. 2016, 55, 1322-1335. [CrossRef]

45. Lee, G. The effectiveness of international knowledge spillover channels. Eur. Econ. Rev. 2006, 50, $2075-2088$. [CrossRef]

46. Krammer, S.M.S. International RD spillovers in emerging markets: The impact of trade and foreign direct investment. J. Int. Trade Econ. Dev. 2010, 19, 591-623. [CrossRef]

47. Levin, A.; Lin, C.F.; Chu, C.S.J. Unit root tests in panel data: Asymptotic and finite-sample properties. J. Econom. 2002, 108, 1-24. [CrossRef]

48. Im, K.S.; Pesaran, M.H.; Shin, Y. Testing for unit roots in heterogeneous panels. J. Econom. 2003, 115, 53-74. [CrossRef]

49. Harris, R.D.F.; Tzavalis, E. Inference for unit roots in dynamic panels where the time dimension is fixed. J. Econom. 1999, 91, 201-226. [CrossRef]

50. Breitung, J. The local power of some unit root tests for panel data. Adv. Ecoometr. 2000, 15, 161-177.

51. Choi, I. Unit root tests for panel data. J. Int. Money Financ. 2001, 20, 249-272. [CrossRef]

52. Kao, C. Spurious regression and residual-based tests for cointegration in panel data. J. Econom. 1999, 90, 1-44. [CrossRef]

53. Pedroni, P. Panel cointegration: Asymptotic and finite sample properties of pooled time series tests with an application to the PPP hypothesis. Econom. Theory 2004, 20, 597-625. [CrossRef]

54. Westerlund, J. New simple tests for panel cointegration. Econom. Rev. 2005, 24, 297-316. [CrossRef]

55. Xing, T.C.; Jiang, Q.C.; Ma, X.J. To Facilitate or Curb? The Role of Financial Development in China's Carbon Emissions Reduction Process: A Novel Approach. Int. J. Environ. Res. Public Health 2017, 14, 39. [CrossRef] [PubMed] 
56. Kiviet, J.F. ON BIAS, Inconsistency, and Efficiency of Various Estimators in Dynamic Panel-Data Models. J. Econom. 1995, 68, 53-78. [CrossRef]

57. Judson, R.A.; Owen, A.L. Estimating dynamic panel data models: A guide for macroeconomists. Econ. Lett. 1999, 65, 9-15. [CrossRef]

58. Calderon, C.; Liu, L. The direction of causality between financial development and economic growth. J. Dev. Econ. 2003, 72, 321-334. [CrossRef]

59. International Monetary Fund. World Economic Outlook, April 2017: Gaining Momentum? Available online: https://www.imf.org/en/Publications/WEO/Issues/2017/04/04/world-economic-outlook-april-2017 (accessed on 25 March 2019).

60. International Monetary Fund. Available online: http://data.imf.org/?sk=F8032E80-B36C-43B1-AC26493C5B1CD33B (accessed on 26 March 2019).

(C) 2019 by the authors. Licensee MDPI, Basel, Switzerland. This article is an open access article distributed under the terms and conditions of the Creative Commons Attribution (CC BY) license (http://creativecommons.org/licenses/by/4.0/). 